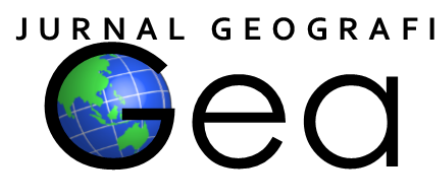

\title{
PERAN PENGEMBANGAN PERKEBUNAN KOPI TERHADAP KONDISI EKONOMI MASYARAKAT DESA PACE KECAMATAN SILO KABUPATEN JEMBER
}

\author{
Andika Pratama Rahmadianto ${ }^{1}$, Fahrudi Akhwan Ikhsan ${ }^{2}$, Bejo Apriyanto ${ }^{3}$ \\ Program Studi Pendidikan Geografi Universitas Jember ${ }^{123}$ \\ masdika070899@gmail.com
}

\begin{abstract}
Pace Village is one of the villages in the Silo District that uses natural resources as a source of livelihood for its citizen's every day. Natural resources used are from the type of coffee and rubber. The majority of the residents earn a living as coffee farmers, especially Robusta coffee. The purpose of this study is to (1) analyze and find the role of coffee development in the socioeconomic condition of the community of Pace Village, Silo District, Jember Regency; (2) characteristics of agricultural income in certain regions; (3) strategies for increasing and marketing the production, productivity, and quality of coffee commodities; (4) Recommendations for increasing coffee production, productivity and quality. The analytical tools used (1) cost analysis and income analysis; (2) descriptive analysis. Agricultural activities in Pace Village are not only focused on coffee plants but some are growing avocado, coconut, sweet potato, sengon and rubber plants.
\end{abstract}

Keywords: Coffee Production and Quality, Economic Condition, Income, Coffee Distribution

\begin{abstract}
ABSTRAK
Desa Pace merupakan salah satu desa di Kecamatan Silo yang memanfaatkan sumber daya alam sebagai sumber mata pencaharian warganya sehari hari. Sumber daya alam yang digunakan yaitu dari jenis kopi dan karet. Mayoritas warganya bermata pencaharian sebagai petani kopi khususnya kopi Robusta. Tujuan penelitian ini adalah sebagai untuk (1) menganalisis dan mengidentifikasi peran pengembangan kopi dalam kondisi sosial ekonomi masyarakat Desa Pace Kecamatan Silo Kabupaten Jember; (2) karateristik pendapatan pertanian di daerah tertentu; (3) strategi peningkatan dan pemasaran produksi, produktivitas, serta kualitas komoditas kopi; (4) Rekomendasi untuk meningkatkan produksi, produktivitas, dan kualitas komuditas kopi. Alat analisis yang digunakan (1) analisis biaya dan analisis pendapatan; (2) analisis deskriptif. Kegiatan pertanian di Desa Pace tidak hanya terfokus dengan tanaman kopi tetapi ada juga yang menanam tanaman alpukat, kelapa, ubi, sengon dan karet.
\end{abstract}

Kata kunci : Produksi dan Kualitas Kopi, Kondisi Ekonomi, Pendapatan, Distribusi Kopi

\section{PENDAHULUAN}

Indonesia merupakan negara penghasil kopi peringkat ke-4 di dunia pada tahun 2002, setelah Brazil, Columbia dan Vietnam. Kopi merupakan salah satu produk komoditi perdagangan perkebunan yang sangat direkomendasikan untuk dikembangkan dan menjadi sumber pendapatan negara serta meningkatkan kondisi ekonomi para pengusaha kopi dan petani kopi yang berjumlah kurang lebih hampir setengah juta jiwa di Indonesia. Kopi merupakan salah satu komoditi perkebunan di Indonesia yang mempunyai tingkatan nilai ekonomis yang cukup tinggi diantara macam-macam tanaman perkebunan lainnya. Wilayah Indonesia mayoritas tanamannya didominasi oleh tanaman kopi karena tanaman kopi sangat cocok ditanam di wilayah yang memiliki iklim subtropis dan tropis. Untuk menempuh 
upaya pengembangan serta peningkatan produktivitas, produksi serta daya saing produk perkebunan perlu adanya kegiatankegiatan yang mendukung di dalamnya. Kegiatan tersebut yaitu (a) Meningkatkan fasilitas produksi baik fasilitas untuk proses penanamannya tanaman kopi tersebut maupun fasilitas untuk proses pengolahannya di pabrik; (b) pengembangan usaha pertanian kopi dengan melakukan inovasi baru dan terobosan baru guna memperbarui cara lama yang sudah usang sehingga dapat memperoleh hasil yang lebih maksimal. Salah satu daerah penghasil kopi di Indonesia adalah Kabupaten Jember, Jawa Timur dengan total 16.882 ha perkebunan kopi dimana 5.601,31 ha diantaranya adalah perkebunan kopi rakyat dengan skala usaha antara $1-2$ ha (Nurdiansyah, Wardana, Tajuddin, \& Al, 2017). Penelitian ini bertujuan untuk menganalisis peran pengembangan perkebunan dan produk kopi terhadap kondisi sosial ekonomi di Desa Pace Kecamatan Silo Kabupaten Jember yang mayoritas mata pencaharian warganya bekerja sebagai petani kopi.

\section{METODE PENELITIAN}

Penelitian ini dilaksanakan di Kebun Kopi Desa Pace Kecamatan Silo Kabupaten Jember. Daerah penelitian ditentukan secara sengaja. Metode yang digunakan dalam penelitian ini adalah metode deskriptif. Metode deskriptif bertujuan membuat diskripsi atau pencanderaan atau gambaran mengenai fakta- fakta, sifat-sifat serta hubungan dari fenomena yang diselidiki pada suatu populasi atau daerah tertentu secara sistematis, faktual, dan akurat. Penggunaan metode ini dengan pertimbangan bahwa Desa Pace merupakan salah satu daerah yang membudidayakan komoditas jahe. Desa Pace merupakan salah satu desa yang mendapat bantuan bibit dari Dinas Pertania untuk pengembangan budidaya kopi. Pengambilan contoh dalam penelitian ini menggunakan metode Total Sampling Penelitian ini menggunakan data primer dan sekunder.

\section{HASIL DAN PEMBAHASAN}

Peningkatan produksi perkebunan kopi di lahan petani-petani tidak terlepas dari beberapa faktor pendukung. Yang pertama adalah adanya inovasi-inovasi baru seperti teknik-teknik serta metode-metode baru dalam usaha tani kopi tersebut. Inovasi tersebut lengkap mulai dari bagaimana cara para petani kopi ini menyebar dan menanam bibit, benih, pupuk, obat-obatan supaya lebih mudah dan efisien daripada cara-cara sebelumnya. Yang kedua sarana prasarana serta peralatan yang digunakan para petani kopi dalam menanam kopi dan para pelaku yang bergerak di dalam bidang pengolahan bibit-bibit kopi yang telah dipanen dan siap diolah menjadi bubuk kopi berkualitas atau minuman kopi siap minum. Yang terakhir yaitu teknologi yang digunakan baik selama proses penanaman bibit kopi sampai proses pengolahan kopi serta proses pemasaran hingga ke tangan konsumen.

Seluruh peningkatan produksi tersebut akan sukses dan berhasil jika dibarengi perubahan yang merata di seluruh sektor. Perubahan yang pertama diawali dari mengadopsi proses teknologi yang terjadi di tingkat para petani. Sumber-sumber teknologi bagi para petai adalah teknik kerja dari petani lain, dalam artian sangat jarang sekali ada petani yang menggunakan teknik yang sama dalam kerja mereka dan pasti berbeda. Misalnya dalam penggunan air dan pupuk, pasti berbeda cara penggunaannya dan dosis pemberiannya dari setiap petani kopi. Perbedaan yang terdapat dikalangan para petani, mengenai teknik yang dipraktekkan dan bahan yang dipergunakan, dapat merupakan sumber teknologi baru yang berharga bagi tiap petani di lokasi penelitian belum melaksanakan metode-metode terbaik (Mutu, Kopi, Di, \& Silo, 2012).

\section{Peran Pengembangan Produksi Usaha Kopi}

Kabupaten Jember merupakan wilayah yang memiliki potensi besar dalam pengembangan usaha perkebunan kopi. Salah satu wilayah yang sangan berpotensi untuk pengembangan perkebunan kopi adalah Kecamatan Silo. Salah satu desa yang memiliki potensi besar terhadap pengembangan perkebunan kopi adalah Desa Pace. Desa Pace memiliki potensi yang sangat besar dan mumpuni dalam urusan pengembangan kopi rakyat karena Desa Pace 
memiliki luas lahan kurang lebih sekitar 5.107 Ha. Dengan kondisi daerah yang memiliki lahan luas menjadikan para petani Desa Pace memiliki keleluasaan dalam menanam dan mengembangkan perkebunan kopi tersebut.

Kegiatan usahatani tanaman kopi dan tahunan yang dilakukan oleh petani kopi Desa Pace menerapkan sistem tanam multiple cropping. Multiple cropping merupakan sistem pola tanam dimana dalam satu lahan tumbuh dua atau lebih tanaman budidaya yang mempunyai umur dan pertumbuhan yang sama, dalam satu baris tanaman terdapat dua atau lebih jenis tanaman(Mutu et al., 2012). Multiple cropping oleh petani kopi Desa Pace diterapkan dikebun kopinya dengan menanami tanaman sela di dekat tanaman kopi yang bernilai ekonomi serta sebagai tanaman penaung kopi seperti tanaman apukat, kelapa, pisang, gadung, pete, sengon dan mahoni.

\section{Pendapatan Kepala Keluarga Petani Kopi di Desa Pace}

Berdasarkan hasil penelitian dapat diketahui bahwa tinggi dan rendahnya pendapatan kepala keluarga petani yang bekerja dengan menggantungkan kubutuhan hidup terhadap panen kopi setiap satu kali musim panen. Pendapatan yang diperoleh setiap petani kopi akan selalu berubah-ubah, tergantung dengan hasil panen. Di mana hasil tersebut akan dijual kepada pengepul untuk memenuhi kebutuhan hidup mereka dalam menanti panen berikutnya.

Reksoprayitno, (2004: 79), pen- dapatan adalah sebagai jumlah penghasilan yang diterima oleh anggota masyarakat untuk jangka waktu tertentu sebagai balas jasa atau faktor-faktor produksi yang telah disumbangkan. Berdasarkan hasil peneitian petani kopi di Desa Pace menunjukkan bahwa pendapatan yang diperoleh dalam satu bulan kepala keluarga petani kopi tergolong rendah yaitu kurang lebih sebesar 1,5 juta dengan jumlah keluarga yang tidak sedikit. Sedangkan kebutuhan hidup semakin hari makin bertambah banyak dan harga barangbarang semakin mahal. Keadaan tersebut mengakibatkan para petani tidak terfokus terhadap tanaman kopi saja, akan tetapi mereka juga menanam dan membudidayakan tanaman lain seperti karet, sengon, kelapa, pisang serta tanaman lainnya yang bisa diperjualbelikan untuk memenuhi kehidupan sehari hari mereka.

Strategi Peningkatan dan Pemasaran Produksi, Produktivitas, serta Kualitas Komoditas Kopi

Berdasarkan hasil penelitian dapat diketahui bahwa kepala keluarga di Kecamatan Balik Bukit melaksanakan pemasaran kopi di Kecamatan Silo seluruhnya di jual kepada agen penjualan/ pengepul yang tersebar di daerah Kecamatan Silo itu sendiri bahkan di luar Kabupaten Jember. Selanjutnya kopi yang telah di jual kepada pedagang atau tengkulak tersebut didistribusikan ke pabrik- pabrik pengolahan kopi hingga di dapatkan hasil kopi dalam bentuk bubuk. Adapun pola pemasaran pertanian kopi dari yang pertama adalah petani kopi kemudian diperjualbelikan kepada agen ataupun tengkulak, kemudian dari agen ataupun tengkulak diberikan kepada pabrik pengolahan supaya biji kopi hasil panen dapat menjadi produk unggulan kopi, setelah diolah dan produknya siap kemudian dipasarkan kepada konsumen, beberapa toko, supermarket serta cafe-cafe yang membutuhkan. Pemasaran yang seperti ini disebabkan jumlah produksinya yang banyak dan juga karena pekerjaan berkebun kopi ini adalah satu-satunya penghasilan terbesar yang didapatkan oleh petani kopi. Sehingga hasil panen harus segera di pasarkan guna memenuhi kebutuhan hidup sehari-hari. Pemasaran yang dilakukakan guna mendapatkan hasil berupa uang atau barang yang dapat dipergunakan petani kopi dalam memenuhi kebutuhan hidupnya dan keluarga. Kotler \& Keller (2012: 20), pemasaran adalah suatu proses sosial dan managerial yang didalamnya individu dan kelompok mendapatkan apa yang mereka butuhkan dan inginkan dengan menciptakan, menawarkan, dan mempertukarkan produk yang bernilai kepada pihak lain. Berdasarkan pendapat tersebut maka dapat disimpulkan bahwa pemasaran merupakan salah satu cara yang dapat digunakan oleh seseorang untuk menawarkan dan mempertukarkan benda atau barang yang dimilikinya dengan apa yang mereka inginkan melalui proses sosial dan juga managerial. 


\section{SIMPULAN}

Peran pengembangan perkebunan kopi bagi penduduk Desa Pace masih tergolong belum merata atau dapat dikatakan hanya beberapa orang saja yang dapat merasakan dampak dari program pengembangan perkebunan kopi tersebut. Dari fakta dilapangan, penghasilan para petani kopi tergolong masih kurang mencukupi untuk kebutuhan dapur keluarganya dan biaya sekolah anak serta kebutuhan lainnya. Para petani juga menanam tanaman lain seperti mahoni, pepaya, sengon, pisang, alpukat, kelapa dan lainnya untuk menambah pendapatan mereka. Produksi kopi Desa Pace sudah distribusi mulai dari pengepul, toko sekitar Desa Pace sampai area Kota Jember.

\section{DAFTAR PUSTAKA}

Adikarta. 2009. "Data PPL Kelompoktani Perkebunan di Kabupaten Jember." Jember: Dinas Kehutanan dan Perkebunan.

Hernanda, E.N.P., Indriani, Y., Kalsum, U. (2017). Pendapatan Dan Ketahanan Pangan Rumah Tangga Petani Padi Di Desa Rawan Pangan. JIIA, VOLUME 5 No. 3, AGUSTUS 2017. Halaman: 283291.

Mutu, D. A. N., Kopi, K., Di, R., \& Silo, K. (2012). Rancangan strategi pengembangan produksi, produktivitas dan mutu komoditas kopi robusta di kecamatan silo kabupaten jember. 6(3).

Kotler \& Keller. 2012. Managemen Pemasaran: Teori dan Aplikasi Dalam Bisnis. Editor Limakrisna, Nanda \& Susilo, Wilhelmus Hary. Mitra wacana Media. Jakarta

Marlina, L., Dharmawan, A.H., Purnamadewi, Y.L. (2017). Peranan Kopi Rakyat Terhadap Perekonomian
Wilayah Kabupaten Lampung Barat. JIIA, VOLUME 5 No. 3, AGUSTUS 2017. Halaman: 292-303.

Nurcahyo, E., Widjaya, S., Kasymir, E. (2017). Hubungan Kompetensi Dan Motivasi Ketua Kelompok Tani Terhadap Pendapatan Usahatani Tebu Program Mitra Mandiri Gunung Madu Plantations Di Kabupaten Lampung Tengah. JIIA, VOLUME 5 No. 3, AGUSTUS 2017. Halaman: 328-334.

Nurdiansyah, Y., Wardana, I., Tajuddin, M., \& Al, N. I. (2017). Menentukan Bibit Kopi yang Cocok Ditanam di Kecamatan Sumberjambe Kabupaten Jember Menggunakan Metode Forward Chaining. 2(3), 148-153.

Reksoprayitno.2004. Sistem Ekonomi dan Demokrasi Ekonomi. Bina Grafika. Jakarta Silaen

Wiguna, Syapta \& Karimi, Syafruddin \& Ridwan, Endrizal. (2019). Dampak Skema Relasi Kopi Sebagai Pengembangan Perekonomian Petani Kopi di Pedesaan. Agriekonomika. 8. 93. 10.21107/agriekonomika.v8i1.5027.

Wijayanti, Reni, V. (2010). Usahatani Kakao dan Tingkat Ekonomi Petani di Desa Banjarasri Kecamatan Kalibawang Kabupaten Kulon Progo. Skripsi. Fakultas Ilmu Sosial dan Ekonomi, Uiversitas Negeri Yogyakarta, Yogyakarta. 